\title{
Front Matter: Volume 7609
}

, "Front Matter: Volume 7609," Proc. SPIE 7609, Photonic and Phononic Crystal Materials and Devices X, 760901 (29 March 2010); doi:

$10.1117 / 12.858990$

SPIE. Event: SPIE OPTO, 2010, San Francisco, California, United States 


\title{
PROCEEDINGS OF SPIE
}

\section{Photonic and Phononic Crystal Materials and Devices $X$}

\author{
Ali Adibi \\ Shawn-Yu Lin \\ Axel Scherer \\ Editors
}

26-28 January 2010

San Francisco, California, United States

Sponsored and Published by

SPIE 
The papers included in this volume were part of the technical conference cited on the cover and title page. Papers were selected and subject to review by the editors and conference program committee. Some conference presentations may not be available for publication. The papers published in these proceedings reflect the work and thoughts of the authors and are published herein as submitted. The publisher is not responsible for the validity of the information or for any outcomes resulting from reliance thereon.

Please use the following format to cite material from this book:

Author(s), "Title of Paper," in Photonic and Phononic Crystal Materials and Devices X, edited by Ali Adibi, Shawn-Yu Lin, Axel Scherer, Proceedings of SPIE Vol. 7609 (SPIE, Bellingham, WA, 2010) Article CID Number.

ISSN 0277-786X

ISBN 9780819480057

Published by

SPIE

P.O. Box 10, Bellingham, Washington 98227-0010 USA

Telephone +1 3606763290 (Pacific Time) · Fax +1 3606471445

SPIE.org

Copyright (C) 2010, Society of Photo-Optical Instrumentation Engineers

Copying of material in this book for internal or personal use, or for the internal or personal use of specific clients, beyond the fair use provisions granted by the U.S. Copyright Law is authorized by SPIE subject to payment of copying fees. The Transactional Reporting Service base fee for this volume is $\$ 18.00$ per article (or portion thereof), which should be paid directly to the Copyright Clearance Center (CCC), 222 Rosewood Drive, Danvers, MA 01923. Payment may also be made electronically through CCC Online at copyright.com. Other copying for republication, resale, advertising or promotion, or any form of systematic or multiple reproduction of any material in this book is prohibited except with permission in writing from the publisher. The CCC fee code is 0277-786X/10/\$18.00.

Printed in the United States of America.

Publication of record for individual papers is online in the SPIE Digital Library.

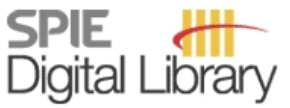

SPIEDigitalLibrary.org

Paper Numbering: Proceedings of SPIE follow an e-First publication model, with papers published first online and then in print and on CD-ROM. Papers are published as they are submitted and meet publication criteria. A unique, consistent, permanent citation identifier (CID) number is assigned to each article at the time of the first publication. Utilization of CIDs allows articles to be fully citable as soon they are published online, and connects the same identifier to all online, print, and electronic versions of the publication. SPIE uses a six-digit CID article numbering system in which:

- The first four digits correspond to the SPIE volume number.

- The last two digits indicate publication order within the volume using a Base 36 numbering system employing both numerals and letters. These two-number sets start with 00, 01, 02, 03, 04, $05,06,07,08,09,0 A, 0 B \ldots 0 Z$, followed by 10-1Z, 20-2Z, etc.

The CID number appears on each page of the manuscript. The complete citation is used on the first page, and an abbreviated version on subsequent pages. Numbers in the index correspond to the last two digits of the six-digit CID number. 


\section{Contents}

ix Conference Committee

\section{PHOTONIC CRYSTAL CAVITIES I}

760908 High-frequency tuning of photonic crystal defect cavity modes using surface acoustic waves [7609-06]

D. A. Fuhrmann, Univ. Augsburg (Germany) and Univ. of California, Santa Barbara (United States); H. Kim, S. M. Thon, Univ. of California, Santa Barbara (United States); J. Jambreck, Univ. Augsburg (Germany); J. Ebbecke, Univ. Augsburg (Germany) and Univ. of Southern Denmark (Denmark); D. Bouwmeester, Univ. of California, Santa Barbara (United States) and Leiden Univ. (Netherlands); P. M. Petroff, Univ. of California, Santa Barbara (United States); A. Wixforth, H. J. Krenner, Univ. Augsburg (Germany)

\section{PHOTONIC CRYSTAL CAVITIES II}

7609 OA Linewidth narrowing and luminescence enhancement in photonic crystal cavities and plasmonic gratings on an Er-doped silicon nitride platform (Invited Paper) [7609-08] Y. Gong, M. Makarova, Stanford Univ. (United States); S. Yerci, R. Li, Boston Univ. (United States); M. Stevens, B. Baek, S. W. Nam, National Institute of Standards and Technology (United States); L. Dal Negro, Boston Univ. (United States); J. Vučković, Stanford Univ. (United States)

7609 OB Plasmonic-photonic hybrid cavity for tailored light-matter coupling (Invited Paper) [7609-09] M. Barth, S. Schietinger, S. Fischer, Humboldt-Univ. zu Berlin (Germany); J. Becker, Univ. of Mainz (Germany); N. Nüsse, Helmholtz-Ctr. Berlin for Materials and Energy (Germany); T. Aichele, Humboldt-Univ. zu Berlin (Germany); B. Löchel, Helmholtz-Ctr. Berlin for Materials and Energy (Germany); C. Sönnichsen, Univ. of Mainz (Germany); O. Benson, Humboldt-Univ. zu Berlin (Germany)

7609 OE Direct measurement of spectrally selective absorption enhancement in Fano resonance photonic crystal cavities on plastic substrates [7609-12]

L. Chen, H. Yang, Z. Qiang, The Univ. of Texas at Arlington (United States); L. Sun, Z. Ma, Univ. of Wisconsin-Madison (United States); J. Xu, The Pennsylvania State Univ. (United States); R. Pate, A. Stiff-Roberts, Duke Univ. (United States); G. J. Brown, Air Force Research Lab. (United States); W. Zhou, The Univ. of Texas at Arlington (United States)

7609 OF An analytical approach for evaluating the optical spectrum emitted from a strongly coupled single quantum-dot photonic-crystal cavity system [7609-13]

E. Ahmadi, H. R. Chalabi, M. Miri, M. Bayat, S. Khorasani, Sharif Univ. of Technology (Iran, Islamic Republic of) 
7609 Ol InGaAsSb LED arrays $(\lambda=\mathbf{3 . 7} \boldsymbol{\mu m})$ with photonic crystals [7609-16]

B. A. Matveev, Yu. M. Zadiranov, loffe Physico-Technical Institute (Russian Federation); A. L. Zakgeim, Microelectronics Ctr. for Research \& Engineering of Submicron Heterostructures (Russian Federation); N. D. Il'inskaya, S. A. Karandashev, M. A. Remennyy, N. M. Stus', A. A. Usikova, loffe Physico-Technical Institute (Russian Federation); A. E. Cherniakov, Microelectronics Ctr. for Research \& Engineering of Submicron Heterostructures (Russian Federation)

\section{DISPERSIVE AND NONLINEAR PROPERTIES OF PHOTONIC CRYSTALS}

$7609 \mathrm{OL}$ Cascaded silicon-nitride integrated spectrometers for wideband high-resolution spectral interrogation [7609-19]

B. Momeni, E. Shah Hosseini, A. Adibi, Georgia Institute of Technology (United States)

7609 OM An efficient self-collimating photonic crystal coupling technique in the RF regime [7609-20] J. N. Sabas, I. O. Mirza, S. Shi, D. W. Prather, Univ. of Delaware (United States)

760900 Chip-scale photonic interconnects for reconfigurable computing [7609-22] A. Sharkawy, O. Ebil, EM Photonics, Inc. (United States); M. Zablocki, S. Shi, D. W. Prather, Univ. of Delaware (United States)

7609 OP Photonic crystal Mach-Zehnder interferometer operating in the self-collimation mode of light [7609-23]

H. M. Nguyen, E. W. J. M. van der Drift, J. Caro, S. Rogge, H. W. M. Salemink, Delft Univ. of Technology (Netherlands)

THREE-DIMENSIONAL PHOTONIC CRYSTAL STRUCTURES

7609 OS Five-beam holographic fabrication of 3D photonic crystal templates using a single diffractive optical element [7609-26]

Y. Lin, A. Harb, K. Lozano, The Univ. of Texas-Pan American (United States); D. XU, K. P. Chen, Univ. of Pittsburgh (United States)

7609 OT GaAs-based woodpile photonic crystal fabricated by two-directional etching method [7609-27]

L. Tang, T. Yoshie, Duke Univ. (United States)

\section{PHONONIC CRYSTAL STRUCTURES}

7609 OV High-efficiency photonic crystal narrowband thermal emitters (Invited Paper) [7609-29] G. B. Farfan, M. F. Su, M. M. Reda Taha, The Univ. of New Mexico (United States); I. El-Kady, The Univ. of New Mexico (United States) and Sandia National Labs. (United States) 
7609 OW Support loss suppression in micromechanical resonators by the use of phononic band gap structures (Invited Paper) [7609-30]

S. Mohammadi, A. A. Eftekhar, Georgia Institute of Technology (United States); A. Khelif, Georgia Institute of Technology-CNRS Joint Lab. (United States); A. Adibi, Georgia Institute of Technology (United States)

7609 0X Elastic filter based on coupled resonator waveguides in phononic crystal slabs (Invited Paper) [7609-31]

A. Khelif, Georgia Institute of Technology-CNRS Joint Lab. (United States) and Institut FEMTO-ST, Univ. de Franche-Comté (France); S. Mohammadi, A. Eftekhar, A. Adibi, Georgia Institute of Technology (United States); B. Aoubiza, Univ. de Franche-Comté (France)

\section{PHOTONIC CRYSTAL FIBERS}

$76090 Z$ Double photonic band gap hollow-core photonic crystal fiber (Invited Paper) [7609-33] F. Benabid, F. Couny, P. S. Light, Univ. of Bath (United Kingdom)

760910 Highly nonlinear photonic crystal fiber with high refractive index core for dental OCT applications [7609-34]

T. Koga, Y. Namihira, T. Kinjo, S. F. Kaijage, S. M. A. Razzak, S. Nozaki, Univ. of the Ryukyus (Japan)

760911 Long-period fiber gratings based on liquid-filled photonic crystal fibers [7609-35]

C.-P. Chen, C.-P. Yu, National Sun Yat-Sen Univ. (Taiwan)

\section{NOVEL EFFECTS AND APPLICATIONS IN PHOTONIC CRYSTAL STRUCTURES}

760913 Chalcogenide glass photonic crystals: progress and prospects (Invited Paper) [7609-37] C. Grillet, M. W. Lee, The Univ. of Sydney (Australia); X. Gai, The Australian National Univ. (Australia); S. Tomljenovic-Hanic, C. Monat, E. Mägi, D. J. Moss, B. J. Eggleton, The Univ. of Sydney (Australia); S. Madden, D.-Y. Choi, D. Bulla, B. Luther-Davies, The Australian National Univ. (Australia)

760915 Photonic crystal switching by the electrophoretic movement of dye ions [7609-39] J. D. Krabbe, Univ. of Alberta (Canada); M. J. Brett, Univ. of Alberta (Canada) and National Institute for Nanotechnology (Canada)

760916 Structural color printing: full color printing with single ink [7609-40] H. Kim, Seoul National Univ. (Korea, Republic of); J. Ge, Univ. of California, Riverside (United States); J. Kim, S.-E. Choi, H. Lee, H. Lee, W. Park, Seoul National Univ. (Korea, Republic of);

Y. Yin, Univ. of California, Riverside (United States); S. Kwon, Seoul National Univ. (Korea, Republic of)

\section{PHOTONIC CRYSTAL WAVEGUIDES}

760918 Wide bandwidth photonic crystal waveguide bends (Invited Paper) [7609-42]

M. Askari, A. Adibi, Georgia Institute of Technology (United States) 
7609 1A Low dispersion slow light in silicon-on-insulator photonic crystal waveguide [7609-44] A. Hosseini, D. Kwong, The Univ. of Texas at Austin (United States); H. Subbaraman, Omega Optics, Inc. (United States); R. T. Chen, The Univ. of Texas at Austin (United States)

7609 1B Compact couplers for overmoded three-dimensional photonic crystal waveguides [7609-45]

B. M. Cowan, Tech-X Corp. (United States); R. L. Byer, Stanford Univ. (United States);

E. R. Colby, R. J. England, Stanford Linear Accelerator Ctr. (United States); M. Lin, Tech-X Corp. (United States); C. McGuinness, Stanford Univ. (United States) and Stanford Linear Accelerator Ctr. (United States); R. J. Noble, Stanford Linear Accelerator Ctr. (United States); B. T. Schwartz, Tech-X Corp. (United States); J. E. Spencer, Stanford Linear Accelerator Ctr. (United States)

\section{MODELING AND SIMULATION OF PHOTONIC CRYSTAL STRUCTURES}

7609 1C Metamaterial-inspired high-absorption surfaces for thermal infrared applications [7609-46] D. W. Peters, P. Davids, J. R. Wendt, A. A. Cruz-Cabrera, S. A. Kemme, Sandia National Labs. (United States); S. Samora, LMATA (United States)

7609 1D Propagation loss analysis in photonic crystal waveguides using a complex-band technique [7609-48]

C. M. Reinke, A. A. Eftekhar, B. Momeni, A. Adibi, Georgia Institute of Technology (United States); X. Zhang, Oak Ridge National Lab. (United States)

7609 IE Stable semi-analytical method for analysis of plasmonic propagation on periodically patterned metal plates [7609-49]

N. Yasrebi, S. Khorasani, H. Karami-Taheri, B. Rashidian, Sharif Univ. of Technology (Iran, Islamic Republic of); A. Hosseini, The Univ. of Texas at Austin (United States)

7609 1G Influence of asymmetry on the band structure of photonic crystals [7609-51]

S. H. Moosavi Mehr, S. Khorasani, Sharif Univ. of Technology (Iran, Islamic Republic of)

$76091 \mathrm{H} \quad$ Ultracompact wave plates by air holes periodic dielectric waveguides [7609-52]

W. Zhang, Xi'an Institute of Optics and Precision Mechanics (China) and Graduate Univ. of Chinese Academy of Sciences (China); J. Liu, Xi'an Institute of Post and Telecommunications (China); W.-P. Huang, McMaster Univ. (Canada); W. Zhao, Xi'an Institute of Optics and Precision Mechanics (China)

\section{POSTER SESSION}

7609 1J Simultaneous two-dimensional nanometric-scale position monitoring by probing a two-dimensional photonic crystal plate [7609-54] K.-C. Hsu, C.-C. Chen, C.-H. Chan, National Central Univ. (Taiwan); P.-F. Chung, Y. Lai, National Chiao Tung Univ. (Taiwan)

7609 1K Refraction properties of fcc and hcp SiO ${ }_{2}$-based colloidal crystals [7609-55]

J. C. Salcedo-Reyes, Pontificia Univ. Javeriana (Colombia)

7609 1L Birefringent selectively liquid-filled photonic crystal fibers [7609-56]

J.-H. Liou, S.-S. Huang, C.-P. Yu, National Sun Yat-Sen Univ. (Taiwan) 
7609 1M Loss-reduced internally liquid-filled photonic crystal fibers [7609-57]

J.-H. Liu, C.-P. Yu, National Sun Yat-Sen Univ. (Taiwan)

7609 1Q Numerical investigation of photonic crystal microcavities in silicon-on-insulator waveguides [7609-62]

S. Burger, F. Schmidt, L. Zschiedrich, Zuse Institute Berlin (Germany) and JCMwave GmbH (Germany)

Author Index 
Downloaded From: https://www.spiedigitallibrary.org/conference-proceedings-of-spie on 26 Apr 2023

Terms of Use: https://www.spiedigitallibrary.org/terms-of-use 


\title{
Conference Committee
}

\author{
Symposium Chair
}

E. Fred Schubert, Rensselaer Polytechnic Institute (United States)

Symposium Cochairs

Liang-Chy Chien, Kent State University (United States)

James G. Grote, Air Force Research Laboratory (United States)

Program Track Chair

Ali Adibi, Georgia Institute of Technology (United States)

Conference Chairs

Ali Adibi, Georgia Institute of Technology (United States)

Shawn-Yu Lin, Rensselaer Polytechnic Institute (United States)

Axel Scherer, California Institute of Technology (United States)

Program Committee

Shanhui Fan, Stanford University (United States)

Abdelkrim Khelif, Georgia Institute of Technology (United States)

Maryanne C. J. Large, The University of Sydney (Australia)

Susumu Noda, Kyoto University (Japan)

Masaya Notomi, NTT Basic Research Laboratories (Japan)

Ekmel Özbay, Bilkent University (Turkey)

Domenico Pacifici, California Institute of Technology (United States)

Dennis W. Prather, University of Delaware (United States)

William J. Wadsworth, University of Bath (United Kingdom)

Yong Xu, Virginia Polytechnic Institute and State University (United States)

Eli Yablonovitch, University of California, Berkeley (United States)

\section{Session Chairs}

1 Present and Future of Photonic Crystals: Special Review Session Ali Adibi, Georgia Institute of Technology (United States)

2 Photonic Crystal Cavities I

Axel Scherer, California Institute of Technology (United States) 
3 Photonic Crystal Cavities II

Marko Loncar, Harvard University (United States)

$4 \quad$ Photonic Crystal Light Emitters

Ali Adibi, Georgia Institute of Technology (United States)

$5 \quad$ Dispersive and Nonlinear Properties of Photonic Crystals

Abdelkrim Khelif, Georgia Institute of Technology (United States)

$6 \quad$ Three-dimensional Photonic Crystal Structures

Ihab F. El-Kady, Sandia National Labs. (United States)

$7 \quad$ Phononic Crystal Structures

Shu Yang, University of Pennsylvania (United States)

8 Photonic Crystal Fibers

Christian Grillet, The University of Sydney (Australia)

9 Novel Effects and Applications in Photonic Crystal Structures

Fetah A. Benabid, University of Bath (United Kingdom)

10 Photonic Crystal Waveguides

Ali Adibi, Georgia Institute of Technology (United States)

11 Modeling and Simulation of Photonic Crystal Structures

Murtaza Askari, Georgia Institute of Technology (United States) 